\title{
Rasionalitas Kebijakan Pro Laktasi Indonesia
}

\author{
Demeiati Nur Kusumaningrum* \\ demeiati.kusumaningrum@gmail.com
}

\begin{abstract}
Abstrak
Menyusui adalah naluri manusia yang berkaitan dengan kehamilan, namun demikian pemerintah Indonesia perlu melindungi ibu dan bayi dengan menerbitkan Peraturan Pemerintah Nomor 33 Tahun 2012. Kebijakan ini memandatkan seluruh pihak termasuk pemerintah daerah, lembaga layanan kesehatan, tenaga medis, dan produsen susu formula agar mendukung pemenuhan periode laktasi (menyusui). Dengan menggunakan pendekatan keamanan manusia, penelitian ini hendak menganalisis apa yang menjadi pertimbangan pemerintah Indonesia dalam menerbitkan PP yang berkaitan dengan aspek kesehatan. Penelitian ini menggunakan metode kualitatif. Data dan informasi diperoleh dari observasi, wawancara mendalam, dan kajian literatur. Hasil penelitian ini menunjukkan PP No.33/2012 dikeluarkan sebagai bentuk komitmen pemerintah untuk mencapai target MDGs terkait jaminan kesehatan ibu dan anak. Adapun kendala dalam penerapan kebijakan ini berasal dari kasus ibu bekerja yang pada umumnya terbatas waktu menyusui, beban pikiran, dan kurangnya fasilitas pojok laktasi di tempat kerja. Tayangan iklan susu formula melalui berbagai ruang publik turut meyakinkan para ibu terhadap manfaat susu formula sehingga menggantikan peran ASI. Selain itu, kurangnya pengetahuan tentang menyusui dari ibu dan keluarga juga menjadi tantangan kesuksesan pemenuhan periode menyusui.
\end{abstract}

Kata Kunci: menyusui, MDGs, kebijakan

\begin{abstract}
Breastfeed is a matter of human nature and maternity, but Indonesian government needs to legitimate and protect the right of mother and baby by establish Government Policy No. $33 / 2012$. It mandated the role of local government, health service institututions, medical expertist, and instan milk producers to support the breastfeed period. This research questioned why the Indonesian Government establish the health policy in dealing with breastfeeding obligation that it sounds crucial problem regarding the human security perspective. This research used qualitative method. Data and information obtained from observation, literature review, and deep interview. This policy is the one of Indonesian committment to achieve MDGs target to ensure mother and baby's health. The obstacles of breastfeed experienced by working mother related to the problem of leisure time, stressful, and facilities in work place. The massive instan milk advertisement through mass media and public sphere are able to influence the society mindsets about the safety and goodness of instan milk for their baby. The lack of access on breastfeed education and knowledge of the mother and family become the rest.
\end{abstract}

Keywords: breastfeeds, MDGs, policy

\section{Pendahuluan}

Tulisan ini hadir atas lahirnya kebijakan pemerintah Indonesia pada 1 Maret 2012 yang mendukung pemberian Air Susu Ibu (ASI) Eksklusif pada bayi usia 0-6 bulan melalui Peraturan Pemerintah (PP) Nomor 33 tahun 2012. Aturan ini

\footnotetext{
* Korespondensi: Jurusan Ilmu Hubungan Internasional, FISIP, Universitas Muhammadiyah Malang, Jl. Raya Tlogomas No.246, Malang, Jawa Timur
} 
mengharuskan pemerintah daerah, fasilitas pelayanan kesehatan, intitusi tempat bekerja, ruang publik, dan seluruh masyarakat untuk mendukung pemenuhan periode laktasi sebagai hak ibu dan anak. Sebagai konsekuensi, tenaga kesehatan dan lembaga layanan kesehatan harus memfasilitasi IMD (Inisiasi Menyusui Dini) bagi ibu yang baru melahirkan. Dalam pasal 8 disebutkan, hanya dokter yang memiliki otoritas untuk menentukan pemberian susu formula atas indikasi medis sesuai dengan standar profesi, pelayanan, dan prosedur operasional. Bagi daerah tertentu yang tidak terdapat dokter, hal ini menjadi tanggungjawab bidan dan perawat. Selain itu, pada pasal 10 menekankan prosedur rawat gabung bagi ibu dan bayi pada Klinik Bersalin, Puskesmas atau Rumah Sakit demi memudahkan pemberian ASI Eksklusif (Kementerian Kesehatan n.d.).

Kebijakan pemerintah terkait dengan pemberian ASI Eksklusif menjadi sebuah peringatan tidak hanya bagi seluruh tenaga kesehatan tetapi juga distributor susu formula. Betapa tidak, PP No. 33 Tahun 2012 Tentang Pemberian ASI Eksklusif melarang setiap tenaga kesehatan untuk mempromosikan susu formula dan hal-hal teknis yang dapat menghambat program pemberian ASI Eksklusif. Selain itu, pasal 19 jelas-jelas melarang distributor susu formula bayi untuk memberikan imingiming, kompensasi, atau contoh produk secara cuma-cuma kepada penyelenggara fasilitas kesehatan, ibu hamil atau ibu yang baru melahirkan dalam rangka pemasaran susu formula. Sehingga, pemasaran seluruh produk susu formula di Indonesia harus memuat peringatan "ASI adalah makanan terbaik bagi bayi” sebagai implementasi pasal 20, di mana hal ini sebagai syarat produsen yang ingin mengiklankan produk susu formula pada media massa dan ruang publik.

Kebijakan Presiden Susilo Bambang Yudhoyono ini patut diapresiasi karena mampu melindungi hak ibu untuk menyusui bayinya di ruang publik. Sejak diterbitkannya PP No. 33 Tahun 2012, tempat-tempat umum seperti ruang terbuka hijau atau taman kota di daerah Malang telah menyediakan "pojok laktasi" untuk mendukung pemberian ASI Eksklusif. Terlepas dari perspektif tentang standar kelayakan masyarakat, hal ini menjadi upaya Pemerintah Daerah untuk mengimplementasikan kebijakan nasional. Fasilitas pojok laktasi terdapat pada beberapa lokasi seperti Taman Trunojoyo, Taman Merbabu, dan Alun-Alun Kota Malang. Beberapa pusat perbelanjaan seperti Malang Town Square (Matos) dan 
Malang Olympic Garden (MOG) telah menyediakan ruang ibu dan bayi, di mana para ibu dapat menyusui bayimya sekaligus mengganti popok.

Kebijakan pro laktasi ini sekiranya turut menarik perhatian para pemangku kebijakan pada instansi pemerintah maupun swasta terhadap hak karyawan perempuan untuk memberikan ASI Eksklusif. Pada umumnya, perkantoran menyediakan lemari pendingin untuk penyimpanan ASI perah para pegawai perempuannya. Jika tidak ada ruang khusus menyusui, para pegawai perempuan dapat menggunakan tempat ibadah (musholla) atau toilet untuk memerah ASI. Dengan didukung oleh penjualan peralatan penunjang ASI secara langsung maupun onlineseperti breastpump, coolerbag, maupun tudung penutup dada- menyusui di ruang publik tidak lagi menjadi kendala berarti.

Komunitas pendukung ASI Eksklusif dan gerakan sosial pro laktasi berkembang secara masif di Indonesia. PP No.33 Tahun 2012 menjadi penguatan hukum bagi berbagai gerakan sosial untuk mengkampanyekan dukungan terhadap ibu menyusui dan sosialisasi pengetahuan tentang laktasi. Perinasia, AIMI, dan Selasih menjadi wadah gerakan sosial tersebut di mana pembangunan wacana dan diskusi publik dipenetrasikan melalui internet. Agenda edukasi dan sosialisasi tentang ASI Eksklusif dan IMD dilakukan melalui akun resmi dan website para tenaga medis serta konselor laktasi. Sebagai contoh, AIMI sebagai LSM yang mendukung kebijakan pro laktasi Indonesia menyebarkan pengetahuan tentang kesehatan ibu dan bayi, program-program edukasi tentang manajemen laktasi, pelatihan konselor laktasi serta konsultasi terkait kendala menyusui dilakukan melalui akun facebook, salah satunya 'AIMI Jawa Timur'. Selain itu, Perinasia juga pernah melaksanakan kegiatan pelatihan 'Manajemen Laktasi' bagi penyelenggara layanan kesehatan bekerjasama dengan RS Syaiful Anwar Kota Malang pada bulan Februari 2014 ${ }^{1}$ Begitu juga dengan Selasih yang melalui website-nya secara terbuka mendukung kebijakan pemerintah untuk memenuhi hak ibu dan bayi dalam pemberian ASI Eksklusif.

Indonesia menjadi studi kasus yang menarik mengingat masalah menyusui yang secara fitrah (nature) menjadi naluri seorang ibu yang telah melahirkan bayinya kini perlu dilegitimasi dan dilindungi melalui terbitnya PP No.33 Tahun 2012. Dengan demikian, penelitian ini hendak menganalisis latar belakang pemerintah dan

${ }^{1}$ Hasil wawancara dengan Kepala Diklit RS UMM. Malang, 27 April 2016 Pk 11.30 
situasi di Indonesia yang mendorong dikeluarkannya secara khusus kebijakan tentang pemberian ASI Eksklusif pada masa pemerintahan Presiden Susilo Bambang Yudhoyono.

\section{Internalisasi Human Security dalam Kebijakan Pembangunan}

Idealisme pembangunan pada masing-masing pemerintahan tidak hanya menyangkut sesuatu yang materiil (pertumbuhan ekonomi) tetapi juga imateriil (kepuasan batiniah). Transformasi ekonomi, politik, dan sosial budaya diharapkan membentuk masyarakat yang hidup dengan layak dan memiliki prospek masa depan yang lebih baik. Sehingga, pemerintah tidak hanya berkewajiban menyediakan fasilitas publik sebagai sarana dan prasarana kegiatan ekonomi tetapi juga kebijakan-kebijakan yang mendukung pembangunan pendidikan, kesehatan, dan spiritual masyarakat (Kusumaningrum, 2014: 1-2). Indonesia sejak masa pemerintahan Presiden Soeharto telah menekankan pentingnya pembangunan manusia (human development) sebagai tujuan nasional pembangunan pada GBHN.

Pembangunan nasional Indonesia tidak hanya ditujukan untuk memenuhi kebutuhan infrastruktur tetapi juga kebutuhan dasar masyarakat sesuai dengan prinsip-prinsip kemanusiaan. Hal ini merupakan dampak internalisasi prinsip-prinsip 'keamanan manusia' atau yang dikenal sebagai konsep 'Human Security' yang mengemuka sebagai paradigma pembangunan baru. Konstruksi paradigma pembangunan ini dimulai sejak lahirnya indikator Human Development Index (HDI) oleh UNDP pada tahun 1994.

The 'logic of security' should be broadened beyond territorial defence, national interests and nuclear detterence to include 'universal concerns' and the prevention of conflicts, but also crucially a cooperative global effort to eradicate poverty and underdevelopment (UNDP, 1994:22). The referent object was shifted from nation-states to that of 'people', and to be 'people-centred' was to be 'concerned with how people live and breathe in a society, how freely they exercise their many choices, how much access they have to market and social opportunities - and whether they live in conflict or in peace' (UNDP, 1994:23). This implied a radical widening of the types of threat and sectors to which security was applicable for food, health, the environment, population growth, disparities in economic opportunities, migration, drug trafficking and terrorism. (Busan\&Hansen, 2009:203)

UNDP menekankan keberhasilan pembangunan tidak hanya menyangkut pendapatan nasional (indikator ekonomi) tetapi bagaimana negara mampu mewujudkan kesejahteraan masyarakat sesuai dengan kebutuhan dasarnya. 
Internalisasi perspektif 'human security' ini mengembangkan diskusi yang lebih luas terkait dengan perlindungan terhadap lingkungan, masalah demografi, dan pembangunan sosial pada forum-forum internasional PBB di kemudian hari.

The concept of human development is much deeper and richer that what can be captured in any composite index or even by a detailed set of statistical indicators. Yet it is useful to simplify a complex reality- and that is what the HDI sets out to do. It is a composite index of achievements in basic human capabilities in three fundamental dimensions- a long and healthy life, knowledge and a decent standard of living. Three variables have been chosen to represent these three dimensions- life expectancy, educational attainment, and income. (UNDP 1997: 44 dalam Kegley Jr. \& Wittkopf 1999:129)

Indonesia menjadi bagian dari masyarakat internasional yang menaruh perhatian khusus terhadap masalah kesehatan ibu dan anak. Mengingat salah satu aspek dari indikator HDI - a long healthy life- adalah bagaimana performa negara mewujudkan kehidupan yang sehat bagi masyarakatnya. Pemberian ASI Eksklusif diyakini secara medis mampu menunjang usia harapan hidup yang lebih panjang pada masing-masing individu mengingat manfaat kesehatan yang diberikan dan telah diakui dalam sisi medis di seluruh dunia.

Menurut Ikatan Dokter Indonesia (IDAI), ASI mengandung komponen makro dan mikro nutrien. Makronutrien adalah karbohidrat, protein dan lemak sedangkan mikronutrien adalah vitamin dan mineral. ASI merupakan makanan yang sempurna bagi bayi dan mendukung metabolisme tubuh agar dapat berjalan lancar dan tubuh berkembang dengan baik. Penelitian membuktikan, beberapa bayi yang mendapat ASI lebih dapat menerima sayur-sayuran pada pemberian pertama fase makannya dibandingkan dengan bayi yang mendapat susu formula. Anak yang diberikan ASI paling sedikit 6 bulan juga lebih jarang mengalami kesulitan makan (picky eaters), sepanjang cara pemberian ASI-nya benar. Kedekatan fisik dengan Ibu selama menyusui memberikan efek kedekatan emosional yang membantu bayi membangun ketenangan batin dan rasa percaya diri. Sehingga, periode laktasi penting bagi tumbuh kembang manusia baik secara fisik maupun psikologis (Hendarto \& Pringgadini, 2013).

Menurut DR Abdul Basith Jamal \& DR Daliya Shadiq Jamal dalam tulisannya di Republika, pemenuhan periode laktasi selama 2 (dua) tahun dapat menghindarkan bayi dari ancaman cacat dan mengurangi resiko paparan penyakit. ASI memperkuat sistem imun dan perkembangan biologis anak di masa depan. 
Berdasarkan riset para ilmuwan, nutrisi ASI dan semua manfaatnya tidak bisa digantikan oleh susu formula.

Beberapa pusat penelitian telah banyak mengadakan eksperimen untuk membuat ASI tiruan, melalui uji coba bahan-bahan kimiawi yang disuntikkan ke dalam kelenjar susu pada beberapa binatang menyusui. Maksud dari eksperimen ini, adalah untuk membuat susu buatan yang memiliki kandungan kimiawi yang sama dengan susu murni (ASI). Dan hasilnya, seperti yang kita dapatkan sekarang ini, di pasaran banyak terdapat susu buatan yang dijual di toko-toko, baik untuk komsumsi bayi, maupun anak-anak, bahkan untuk orang dewasa. Namun para ilmuwan berdasarkan penelitian yang mereka lakukan menegaskan, bahwa susu buatan mustahil dapat menggantikan fungsi susu murni, karena kandungan yang dimiliki keduanya tidak bisa sama persis. Tentunya, pengakuan di atas, menunjukkan kegagalan susu buatan dalam memainkan perannya sebagai pengganti susu murni (ASI). Bahkan beberapa penelitian telah dilakukan untuk menganalisa kandungan zat yang terdapat dalam susu buatan. Hasil dari penelitan itu menyatakan bahwa susu buatan tidak aman dan memiliki kemungkinan untuk mengandung bahan-bahan yang dapat mengakibatkan kerusakan sel tubuh. (Republika 2014)

Ditilik dari sisi sains, ASI secara alami merupakan makanan yang terbaik bagi bayi dan mampu memperkuat sistem imun sehingga memberikan dampak kekebalan terhadap berbagai penyakit. Dalam konteks psikologis, pemberian ASI mampu membangun kedekatan emosional dan ikatan batin antara ibu dan anak sehingga berpengaruh terhadap sikap dan mentalnya sebagai seorang individu di masa depan. Sehingga, kebijakan pemerintah Indonesia melalui PP No. 33 Tahun 2012 merupakan legitimasi dan perlindungan hukum terhadap hak ibu dan anak untuk memperoleh kesehatan yang optimal melalui pemberian ASI Eksklusif. Jika masingmasing individu masyarakat Indonesia memiliki kesehatan yang prima, diharapkan kegiatan ekonomi mampu berjalan dengan lancar (produktifitas) sehingga berdampak terhadap kesejahteraan secara umum, mengingat masyarakat merupakan aset pembangunan nasional.

\section{Tantangan Periode Laktasi dan Perubahan Sosial Budaya}

Kebijakan pemerintah tentang kewajiban pemberian ASI Eksklusif merupakan respon dari perubahan sosial di Indonesia terkait konsumsi susu formula yang cukup tinggi dan minimnya pengetahuan tentang manfaat ASI serta dinamika masalah menyusui. Pertama, masifnya iklan susu formula melalui media massa dan media ruang publik mampu mengubah pemikiran ibu-ibu di Indonesia bahwa susu formula merupakan pengganti ASI dan aman dikonsumsi bagi bayi. Meskipun para 
ibu memiliki kapasitas untuk menyusui, susu formula dianggap makanan pelengkap yang mampu menambah berat badan bayi. Kedua, susu formula menjadi pilihan utama bagi para ibu bekerja yang tidak bisa secara intensif menyusui bayinya. Mengingat bayi tersebut diasuh oleh pihak lain seperti anggota keluarga atau layanan penitipan bayi, pemberian susu formula dianggap praktis dan memudahkan pihak lain tetap sabar mengasuh bayinya. Ketiga, pemberian susu formula dilakukan para ibu yang tidak mampu memerah ASI dengan alasan kuantitas kurang, tidak mampu membeli peralatan laktasi yang dianggap mahal, dan terkendala waktu dan tenaga dalam memerah ASI di tempat bekerja. Waktu istirahat yang cukup pendek dan tidak tersedianya lokasi khusus (pojok laktasi) di tempat bekerja sehingga tidak memungkinkan memerah ASI menjadi alasan utama. Kesibukan di tempat kerja yang penuh tekanan juga berpengaruh terhadap stress yang pada akhirnya mempengaruhi jumlah produksi ASI. Keempat, tidak semua penyelenggara layanan kesehatan di Indonesia memiliki prosedur atau kebijakan tertulis terkait dengan fasilitas dan upayaupaya yang menjamin pemberian ASI Eksklusif sehingga masih ada peluang bagi para ibu untuk memberikan susu formula pada bayinya.

Pada dimensi sosial, menyusui merupakan hal yang lumrah atau naluriah bagi perempuan Indonesia. Mereka bisa menyusui bayinya kapan saja dan di mana saja. Sebagian besar perempuan yang akan menikah telah mendapatkan sosialisasi pengetahuan tentang kesehatan reproduksi termasuk periode laktasi dari Bidan atau lembaga kesehatan yang bekerjasama dengan KUA. Hal ini sebagai syarat kepengurusan surat nikah. Selain itu, permasalahan tentang manajemen rumahtangga, dan hubungan antara ibu dan anak dalam tradisi di Indonesia senantiasa disampaikan oleh orang tua kepada anak-anaknya melalui bahasa tutur ketika mereka menginjak akil baliq (mature). Dengan demikian, diasumsikan sebagian besar perempuan telah siap menjadi seorang istri dan seorang ibu di masa depan.

Nyatanya, permasalahan tengah dialami masyarakat Indonesia seiring dengan meningkatnya angka perempuan bekerja. Kesetaraan gender yang mengemuka di Indonesia berdampak pada rendahnya angka menyusui ${ }^{2}$. Kendala pemenuhan ASI Eksklusif 0-6 bulan kelahiran bayi mulai dialami para ibu bekerja yang memiliki tugas dan tanggung jawab di luar rumah. Hal ini terkait waktu yang

${ }^{2}$ Hasil wawancara dengan Konselor Laktasi RS Hermina Tangkuban Perahu Malang. 26 Maret 2016 $\mathrm{Pk} 10.00$ 
kurang untuk bounding dengan bayinya, minimnya energi dan nutrisi yang baik sehingga berpengaruh bagi kualitas dan kuantitas ASI. Sementara, ibu bekerja sering kesulitan untuk pulang ke rumah atau mengakses tempat penitipan anak (TPA) karena kendala jarak dan waktu. Jika ibu bekerja tersebut sangat antusias dalam memberikan ASI Eksklusif pada bayinya, tentunya alasan ini dapat diatasi dengan membeli peralatan pendukung laktasi seperti breastpump, heater, coolerbag, botol khusus penyimpan ASI, dan tudung pelindung dada untuk memfasilitas memerah ASI di tempat kerja. Namun sayang sekali, perlengkapan laktasi dengan kualitas yang baik harganya tidak murah. Sehingga, para ibu yang pesimis dan terkendala finansial pada umumnya beralih untuk memberi susu formula pada bayinya.

Selain itu, ASI perah memiliki masa kadaluarsa baik disimpan pada coolerbag maupun lemari pendingin. Meskipun disediakan di tempat kerja, jarak tempuh bagi ibu bekerja di luar kota menjadi tantangan tersendiri. Sementara, jasa layanan antar ASI masih dilayani di kota-kota besar di Indonesia. Kerepotan dalam menjaga kualitas ASI perah dan penyediaan segala piranti pendukungnya sering membuat para ibu berputus asa dan beralih ke susu formula. Mengingat para ibu yang bekerja di luar kota tidak semua difasilitasi oleh kendaraan pribadi yang aman dan nyaman. Belum lagi, rasa malu, tabu dan tidak nyaman bagi ibu untuk memerah ASI di ruang publik membuat mereka memadukan pemberian ASI dengan susu formula. Adapun tidak semua anggota keluarga yang mengasuh bayi memiliki kapasitas untuk memberikan ASI perah dengan sendok. Sehingga, kebiasaan bayi meminum ASI melalui botol dot juga mempengaruhi menurunnya minat bayi untuk menyusu pada ibunya. Sehingga, para ibu yang mengalami hal ini melirik susu formula sebagai pelengkap ASI dengan anggapan anaknya sudah malas minum ASI.

Kompleksitas menurunnya angka keberhasilan menyusui di Indonesia juga dipengaruhi oleh pergeseran paradigma di masyarakat terkait dengan kesuksesan penjualan susu formula. Melalui tayangan iklan yang lebih dari $3 \mathrm{x}$ sehari pada berbagai stasiun televisi nasional, membuat ibu-ibu percaya bahwa kandungan susu formula sangat aman dan bisa melengkapi kebutuhan gizi bayi. Apalagi merek susu formula di pasaran didominasi oleh brand atau lisensi luar negeri. Masih berkembang asumsi masyarakat di mana susu yang harganya lebih mahal adalah susu yang lebih berkualitas dan produk yang berkualitas pada umumnya merk atau produksi luar negeri. Ditambah dengan pesimisme kaum ibu bahwa ASI yang diproduksi secara 
kuantitas dan kualitas kurang mencukupi bagi bayi. Bayi dianggap kurang berat badannya atau boleh dibilang performa bayi kurang 'ideal' menurut orangtuanya. Sehingga, susu formula menjadi solusi menambah berat badan bayi.

Berdasarkan wawancara dengan berbagai narasumber secara random, tidak semua ibu mendapat pengetahuan yang cukup tentang kesehatan bayi dan manajemen laktasi. Hal ini dikuatkan oleh pendapat para tenaga medis dan konselor laktasi yang melakukan edukasi dan pendampingan (program ASI Eksklusif) di Rumah Sakit ${ }^{3}$. Ada pasien yang beranggapan ASI Eksklusif adalah pemberian ASI sampai usia 2 tahun dan boleh diselingi dengan tambahan susu formula. Ada juga ibu yang merasa pesimistik dengan berat badan anaknya yang dirasa terlalu kurus meskipun minum ASI, sehingga susu formula dianggap solusi untuk menambah berat badan. Walaupun mereka mendapat konseling dan informasi tentang manajemen laktasi, tidak membuat para ibu meninggalkan konsumsi susu formula pada bayinya.

Ironisnya, lemahnya keyakinan ibu untuk pemberian ASI Eksklusif dipengaruhi oleh doktrin para anggota keluarga yang pada umumnya mengasuh sang bayi, seperti nenek atau tetangga terdekat di mana bayi perlu diberikan tambahan susu formula supaya cepat gemuk meskipun sang ibu memiki kapasitas menyusui dengan baik. Bahkan tidak jarang para ibu meminta rekomentasi dokter anak terkait susu formula yang cocok dan berkualitas paling baik. Adapun pembicaraan mengenai masalah ASI, makanan pendamping ASI, dan pemberian susu formula pada umumnya didapatkan para ibu dari 'sharing' dengan teman-teman komunitasnya melalui forum arisan atau pertemuan informal dari komunikasi jejaring sosial. Sehingga, ketepatan informasi dan pengetahuan tentang manfaat ASI merupakan suatu topik yang konstruktif.

Dalam hal performa bayi, masih banyak yang beranggapan bayi kurus adalah bayi kurang gizi, sementara tolak ukur untuk 'kurus' dan 'gemuk' diyakinkan melalui penilaian visual. Berdasarkan observasi, para ibu belum teredukasi perihal standar kesehatan bayi dan sebagian besar terpengaruh (membanding-bandingkan) dengan penampilan fisik bayi lainnya dalam lingkungan sosial terdekat. Identifikasi bayi sehat adalah bayi gemuk dengan pipi tembem, lengan dan paha kenyal serta kulit

\footnotetext{
${ }^{3}$ Hasil wawancara dengan Konselor Laktasi RS Hermina Tangkuban Perahu Malang. 26 Maret 2016 Pk 10.00 dan Bidan RS UMM pada 2 Mei 2016 pk 15.30
} 
yang segar. Bahkan tidak banyak yang mengetahui tentang pengukuran BMI (body mass index) atau standar kelayakan gizi WHO kecuali para ibu yang rajin ke Posyandu atau bergabung dalam komunitas pro laktasi Indonesia seperti AIMI, Perinasia, dan Selasih.

Kendala menyusui paling banyak dirasakan oleh ibu bekerja di sektor publik atau instansi yang menuntut pelayanan prima. Beberapa perempuan bekerja di sektor industri dan instansi pemerintah di luar kota terpaksa menitipkan bayinya untuk diasuh anggota keluarga atau layanan penitipan bayi (TPA, Baby Day Care, Baby School, dsb.). Para ibu pada akhirnya memberikan susu formula pada bayinya karena kendala waktu, energi, dan kuantitas ASI. Waktu adalah permasalahan di mana ibu harus berangkat pagi-pagi untuk bekerja di luar kota yang menempuh kurang lebih 2 jam perjalanan. Sehingga sering menimbulkan stress dan mengurangi frekuensi menyusui. Energi adalah kendala di mana karena kesibukan dan aktifitas bekerja menghalangi mereka lebih sering menyusui bayinya karena kelelahan. Kapasitas pemberian ASI dilakukan hanya ketika mereka pulang dari bekerja. Itu pun bayi kadang sudah tidak merespon dengan baik karena lebih sering mendapatkan ASI atau susu formula melalui botol dot yang dikenal secara medis sebagai masalah 'bingung puting' pada bayi. Kuantitas ASI secara medis menjadi kendala apabila frekuensi menyusui berkurang, maka kuantitas ASI pun berkurang. Sementara, ibu yang bekerja di sektor formal rata-rata memiliki kewajiban 8 jam berada di ranah publik. Dengan tingkat stress lingkungan kerja dan asupan gizi yang kurang baik, maka kuantitas ASI yang dihasilkan semakin menurun. Hal ini membangun keyakinan bahwa ASI sudah tidak keluar atau tidak diproduksi sehingga membuat para ibu beralih kepada susu formula sebagai pengganti ASI.

Kebijakan manajemen lembaga layanan kesehatan seperti klinik bersalin, puskesmas dan rumah sakit yang belum menerapkan prosedur tertulis tentang dukungan terhadap pemberian ASI Ekskusif juga menjadi latar belakang diterbitkan PP No.33 Tahun 2012. Prosedur pelayanan lembaga kesehatan pada umumnya memberikan kebebasan pada pasien bersalin dalam menentukan apakah bayinya diberikan ASI Ekskluisif atau susu formula. Mengingat pihak penyelenggara kesehatan hanya membantu proses kelahiran dan menjamin kesehatan ibu dan bayi pasca melahirkan, sementara pemberian ASI menjadi pilihan pasien (ranah privat). Padahal tidak semua ibu memiliki pengetahuan yang cukup tentang manajemen 
laktasi dan pentingnya ASI Eksklusif. Hal ini dikuatkan dari pendapat tenaga kesehatan yang mencatat dari 100 persen pasien melahirkan di RS UMM Malang hanya 50 persen yang teredukasi ${ }^{4}$.

Selain itu, sebelum terbit kebijakan pemerintah, tidak banyak rumah sakit, puskesmas, atau klinik bersalin secara jelas menerapkan kebijakan rawat gabung. Hanya lembaga layanan kesehatan yang mengkampanyekan dirinya "pro ASI Eksklusif"/ "Pro IMD"/ "Sayang Ibu dan Bayi" yang betul-betul melakukan sosialisasi dan pendampingan manajemen laktasi sebelum dan setelah melahirkan, disiplin IMD, dan edukasi tentang kesehatan bayi dan ibu baru melahirkan, dan dukungan fasilitas rawat gabung ibu dan bayi.

Iklan yang cukup masif melalui media massa dan ruang publik tidak hanya mampu mempengaruhi pemikiran para ibu terhadap jaminan keamanan dan kesehatan bayi mengkonsumsi susu formula tetapi juga lemahnya prosedur larangan pemasaran produk susu formula baik secara langsung maupun tidak langsung oleh lembaga layanan kesehatan (Klinik Bersalin, Puksesmas dan Rumah Sakit). Sebelum kebijakan ini diterbitkan, masih ada promosi susu formula secara tidak langsung melalui rekomendasi dokter, perawat anak atau bidan yang bertanggungjawab menangani persalinan. Meskipun tenaga kesehatan tetap memenuhi kode etik kedokteran, peluang pemasaran masih tergolong lebih tinggi dibandingkan melalui swalayan pada umumnya. Masyarakat lebih mendengarkan saran tenaga medis daripada hanya sekedar potongan diskon penjualan ritail. Produsen susu formula pun tidak segan-segan memberikan kompensasi penjualan produk susu formula dengan membantu pengembangan riset dan pembangunan infrastruktur lembaga layanan kesehatan yang menajadi mitra. Fenomena ini telah menjadi rahasia umum, seiring dengan berkembangnya bisnis farmasi di Indonesia ${ }^{5}$.

\section{Komitmen terhadap Target Millenium Development Goals (MDGs)}

MDGs lahir sebagai respon masyarakat internasional terkait partisipasi pembangunan dan distribusi kesejahteraan di seluruh dunia. Kesenjangan menjadi masalah utama negara-negara berkembang di mana masih banyak individu yang

\footnotetext{
${ }^{4}$ Hasil wawancaa Bidan RS UMM pada 2 Mei 2016 pk 15.30

${ }^{5}$ Hasil wawancara dengan Konselor Laktasi RS Hermina Tangkuban Perahu Malang. 26 Maret 2016 Pk 10.00
} 
hidup di bawah garis kemiskinan, kurangnya kesempatan menempuh pendidikan dasar, tingginya angka buta huruf bagi perempuan, kesempatan kerja yang lebih kecil bagi perempuan, tingginya angka kematian ibu dan anak, penyebaran AIDS dan kerusakan lingkungan. Indonesia menjadi salah satu negara yang berkomitmen dalam membangun kehidupan masyarakat yang sejahtera secara lahir dan batin, sehingga pemerintah ikut menandatangani Deklarasi Millenium pada pertemuan PBB tahun 2000 (Kemlu RI 2009 dalam Kusumaningrum, 2014: 70-72).

Kesepakatan MDGs berhasil menyeragamkan target pembangunan internasional yang meliputi: 1.) Pemberantasan kemiskinan dan kelaparan ekstrim, 2.) Pencapaian pendidikan dasar yang universal, 3.) Promosi kesetaraan gender dan pemberdayaan perempuan, 4.) Pengurangan tingkat mortalitas bayi, 5.) Peningkatan kesehatan ibu, 6.) Pemberantasan HIV/AIDS, malaria dan penyakit endemik lainnya, 7.) Pencapaian kelestarian lingkungan hidup, dan 8.) Pengembangan kemitraan global untuk pembangunan. Sehingga, lahirnya kesepakatan MDGs menandai kembalinya peran negara sebagai instrumen institusional yang bertanggungjawab dalam mewujudkan kesejahteraan masyarakat. Pencapaian target MDGs didukung oleh kemitraan internasional terkait sumber daya manusia (tenaga ahli) dan sumber daya finansial (pinjaman luar negeri).

Terbitnya PP No.33 Tahun 2012 menjadi implementasi kebijakan pemerintah dalam menyukseskan target MDGs terutama pada aspek pengurangan tingkat mortalitas bayi dan peningkatan kesehatan ibu. Pemberian ASI Eksklusif menjadi sarana pembangunan sistem imunitas pada bayi di masa pertumbuhannya dan sekaligus menjadi makanan utama yang paling cocok sesuai dengan kondisi di masa 0-6 bulan kelahirannya. Selain itu, pemberian ASI diyakini bermanfaat bagi pemulihan kondisi kesehatan ibu pasca melahirkan dan mengurangi resiko penyakit kanker payudara. Secara psikologis, pemberian ASI pada bayi membantu ibu melewati masa-masa stress pasca melahirkan yang dikenal dengan sindrom 'baby blues'. Kedekatan ibu dan bayi memberikan dampak relaksasi dan 'phsycological healing' sehingga membantu mengurangi stress dan menstabilkan tekanan darah. Hal ini pada akhirnya berguna bagi ibu untuk mempertahankan kesehatan jiwa dan membangun kepercayaan diri kembali.

Kampanye kebijakan pro laktasi di Indonesia oleh pemerintah dilaksanakan di bawah tanggungjawab Kementerian Pemberdayaan Perempuan dan 
Kementerian Kesehatan. Salah satu agenda rutin adalah perayaan tahunan Pekan Air Susu Ibu Sedunia (PAS) pada minggu pertama bulan Agustus sebagai peringatan World Breastfeeding Week (WBW). Pada tahun 2013, PAS mengusung tema global "Breastfeeding Support: Close to Mothers" yang diterjemahkan secara nasional sebagai "Dukungan Menyusui: Lebih Dekat Dengan Ibu". Program ini bertujuan untuk menarik dukungan dan peran teman sebaya (sesama ibu menyusui) dalam mendukung keberhasilan menyusui. Dukungan menyusui oleh teman sebaya ini juga dapat dilaksanakan dalam komunitas atau kelompok-kelompok pendukung ibu menyusui (KP-ASI atau KP-Ibu) sebagai wahana saling berbagi ilmu pengetahuan seputar menyusui. Umumnya pembina KP-ASI adalah bidan ataupun konselor menyusui di wilayah setempat. Bersamaan dengan peringatan PAS 2013, Kementerian Kesehatan bekerjasama dengan Lintas Program dan Sektor Terkait (Organisasi Profesi dan LSM) menyelenggarakan Lomba Kelompok Pendukung ASI bagi KPASI yang ada di 33 Propinsi dan KP-ASI yang ada di Tempat Kerja se-Jabodetabek (Kementerian Kesehatan 2013). Berdasarkan pemaparan di atas, kebijakan pro laktasi diterbitkan demi mencapai performa pemerintahan yang akuntabel dan responsif dalam kerangka MDGs. Indonesia secara tegas menyatakan komitmennya untuk mewujudkan kesehatan ibu dan anak melalui kewajiban semua pihak untuk mendukung pemberian ASI Eksklusif.

\section{Kesimpulan}

Kebijakan pro laktasi Indonesia dengan terbitnya PP No. 33 Tahun 2013 menandai komitmen pemerintah dalam mewujudkan kesejahteraan masyarakat khususnya pada aspek kesehatan ibu dan anak. Pemberian ASI Eksklusif membutuhkan dukungan semua pihak mengingat kendala teknis para ibu terkait minimnya pendidikan dan sosialisasi, serta kendala institusional dalam hal prosedur layanan kesehatan, fasilitas di ruang publik, dan perlindungan hak ketenagakerjaan. Peraturan tentang pemberian ASI Eksklusif diyakini sebagai upaya yang pada akhirnya mewajibkan ibu untuk memenuhi hak anak dan kewajiban semua pihak untuk menciptakan lingkungan dan fasilitas yang mendukung pemenuhan periode laktasi.

Sayangnya, kewajiban produsen mencantumkan konten "susu formula bukan pengganti ASI" pada produknya sesuai pasal 20 tidak kemudian mengurangi 
iklan susu formula pada media massa dan ruang publik. Selain itu, belum ada tindakan hukum terkait pelanggaran tenaga medis atau penyelenggara layanan kesehatan yang mempromosikan susu formula karena ketentuan pelanggaran yang dimaksud dalam PP No. 33 Tahun 2012 bersifat delik aduan. Sementara, legalisasi kebijakan terkait pemasaran susu formula baik secara langsung maupun tidak langsung lebih mengarah pada ketentuan etis (norma kepantasan) daripada standar kebijakan pelayanan (SOP) manajemen rumah sakit (norma kepatuhan). Dengan demikian, edukasi, sosialisasi, dan kampanye tentang ASI Eksklusif perlu diupayakan lebih masif.

\section{Referensi}

Busan, Barry. \& Hansen, Lene. 2009. "Widening and Deepening Security" dalam The Evolution of International Security Studies. United States. Cambriedge University Press.

Hendarto, Aryono \& Pringgadini, Keumala. 2013. "Nilai Nutrisi Air Susu Ibu" dalam Buku Bedah ASI. Publikasi IDAI 27 Agustus 2013. Diakses 5 November 2015 pada http://idai.or.id/artikel/klinik/asi/nilai-nutrisi-air-susu-ibu

Kegley Jr., Charles W. \& Wittkopf, Eugene R. 1999. "The Plight and Policy Posture of the Less Developed Global South" dalam World Politics Trend and Transformation. Seventh Edition. United States. Macmillan Press Ltd.

Kementerian Kesehatan RI. (n.d.) Peraturan Pemerintah Nomor 33 Tahun 2012 Tentang Pemberian Air Susu Ibu Eksklusif. Presiden Republik Indonesia. Diakses $\quad 5 \quad$ November 2015 pada http://www.gizi.depkes.go.id/download/Kebijakan\%20Gizi/PokokPokok\%20PP\%20Nmr\%2033\%20Thn\%202012\%20Ttg\%20Pemberian $\% 20$ ASI $\% 20$ Eksklusif.pdf

Kementerian Kesehatan RI. 2013. "Dukungan Menyusui: Lebih Dekat Dengan Ibu" dalam Pekan ASI Sedunia, 2 Agustus 2013. Diakses pada 19 April 2016 pada http://gizi.depkes.go.id/dukungan-menyusui-lebih-dekat-denganibu

Kusumaningrum, Demeiati Nur. 2014. "Pembangunan dan Bantuan Luar Negeri" dalam Ekonomi Politik Kerjasama Pembangunan. Gonda Yumitro (Ed.). Yogyakarta. Gre Publishing. 
Republika Online. 2014. "Al Quran dan Sains: Pentingnya Air Susu Ibu (ASI)". Publikasi Republika 11 Agustus 2014. Diakses 5 November 2015 pada http://www.republika.co.id/berita/dunia-islam/islamdigest/11/08/14/lpweqq-alquran-dan-sains-manfaat-air-susu-ibu-asi 